\title{
EFFECT OF DIETARY ADDITION OF LUPIN AND/OR FENUGREEK SEEDS ON THERMO-RESPIRATORY RESPONSE AND SOME BLOOD CONSTITUENTS OF RAHMANI SHEEP
}

\author{
M. Kobeisy ${ }^{* 1}$, I.A. Soliman ${ }^{1,}$ S.F Mohamed ${ }^{2}$ and A. Al-Khateeb ${ }^{1}$ \\ 1- Animal Production Department, Faculty of Agriculture, Assiut University, Assiut, Egypt, 2- Animal \\ Production Department, Faculty of Agriculture, Al-Azhar University, Assiut, Egypt \\ *mostafa_kobeisy@yahoo.com
}

SUMMARY

This study was conducted to investigate the influence of dietary addition of lupin and /or fenugreek seeds on thermo-respiratory response and some blood constituents of Rahmani sheep. Twenty Rahmani lambs of about 3.5 to 4 months old and body weight of $18.8 \pm 0.5 \mathrm{~kg}$ were distributed in four experimental groups. The control group $(C)$ was fed concentrate feed mixture (CFM), termis (Lupin) group (L) was fed CFM supplemented with 4 $\%$ lupin seeds, fenugreek $(F)$ group was fed CFM supplemented with $8 \%$ fenugreek seeds and lupin with fenugreek (LF) group was fed CFM supplemented with $2 \%$ lupin seeds and $4 \%$ fenugreek seeds. Respiration rate and rectal, skin ear and wool temperatures were tested biweekly and blood samples were taken monthly for determination of some blood constituents. The experimental period was extended for 150 days. The data were statistically analyzed using GLM procedures of SAS (1996). The results indicated that the respiration rate, rectal temperature and skin, ear and wool temperatures tended to increase in animals fed $L$ and $L F$ seeds and there were no significant differences among $L, F$ and $L F$ diets. There were no significant differences in average value of hemoglobin and PCV, \% among lambs fed lupin and/or fenugreek diets. Ration supplemented with L and $F$ had the lowest value of serum glucose concentration in Rahmani lambs compared to the other diets. In particular, lupin diet tended to decrease serum glucose particularly during the second month of experimental period. Animals fed on LF tended to have higher values of serum total protein. Lambs fed on a diet containing $F$ seeds tended to have less serum total proteins than other treatments. Fenugreek feeding tended to decrease serum cholesterol. Serum triglyceride levels were significantly differed among different rations and periods. Serum triglycerides decreased by about 16 and $15 \%$ due to $L$ and $F$ feeding at $I^{\text {st }}$ month of the experimental period, the corresponding values at $4^{\text {th }}$ month of the experimental period were 10 and $11 \%$, respectively. The overall means of serum urea-nitrogen concentrations were lower $(P<0.05)$ in lambs fed LF seeds than those fed control diet. However, feeding $L$ or $F$ tended to increase serum urea- nitrogen of lambs. The overall means of serum creatinine were not significant among animals fed $L, F$ and $L F$ seeds. The overall means of serum AST and ALT concentrations were not significantly affected by feeding $L$ and $F$ seeds. In conclusion: Lupin or fenugreek seeds tended to have hypoglycemic effects, fenugreek seeds tended to decrease serum cholesterol and feeding both lupin and fenugreek seeds had no deleterious effects on kidney or liver function.

Keywords: lupin, fenugreek, thermo-respiratory response, blood constituents, sheep

\section{INTRODUCTION}

Legumes as a source of plant protein are suitable crops having good potential in the Egyptian agriculture. In recent years, there is an increased interest in the use of the seeds of temperate grain legumes such as lupin and fenugreek as animal feed supplements. Several studies in animal nutrition showed that adding some spices or medicinal and aromatic plants to the diets of sheep, goats, rabbits, chicken, cows and buffaloes had favorable effects on live weight gain, feed intake, feed efficiency and nutrient digestibility (Hanafy, 1995; Karaly 1995; Gaber et al., 1996; Mir et al., 1998; Youssef et al., 1998; Abol-Fotouh et al., 1999; Allam et al., 1999; ElAyek et al., 1999 and El-Saddany et al., 1999). Moreover, lupin and fenugreek seeds may have some effects on blood constituents. Clinical and experimental studies have documented antidiabetic and antiatherosclerotic effects (Ajabnoor and Tilmisany, 1988; Sharma and Raghuram, 1990). However, due to high content of quinolizidine alkaloids, which make the seeds bitter may have some effects on liver and kidney functions, particularly high levels of such seeds. Therefore, this study was conducted to examine the effect of lupin (Lupinus termis) and fenugreek (Trigonella foenum graecum) seeds on thermorespiratory response and some blood parameters in Rahmani lambs.

\section{MATERIALS AND METHODS}

This study was carried out in the Experimental Farm of Animal Production Department, Faculty of Agriculture, Al-Azhar University, Assiut Branch. The present work aimed to study the effect of lupin and /or fenugreek seeds supplemented rations on thermorespiratory response and some blood constituents of Rahmani lambs.

\section{Animals and Management:}

A total number of 20 Rahmani lambs of about 3.5 to 4 months old and their live body weight averaged $18.8+0.5 \mathrm{Kg}$ were divided into four treatment groups similar in body weight. A control group (C) was fed concentrate feed mixtures (CFM), termis (Lupin) group (L) was fed CFM supplemented with $4 \%$ lupin 
seeds, fenugreek (F) group was fed CFM supplemented with $8 \%$ fenugreek seeds and lupin with fenugreek (LF) group was fed CFM supplemented with $2 \%$ lupin seeds and $4 \%$ fenugreek seeds. The animals were fed $80 \%$ concentrate and wheat straw ad libitum. Animals were fed in groups two times daily (at 8:00 a.m. and 6:00 p.m.). Water was offered three times daily at 8:00 a.m., 12:00 noon and 6:00 p.m. The formulation of CFM with additives are shown in Table (1) while the chemical analysis of rations are shown in table (2). Rations were formulated to be isonitrogenous $(16 \% \mathrm{CP})$ and isocaloric / isoenergetic (74\% TDN).

Table 1. Formulation of the concentrate feed mixtures

\begin{tabular}{lllll}
\hline Ingredient (\%) & \multicolumn{4}{c}{ Rations } \\
\cline { 2 - 5 } & $\mathrm{C}$ & $\mathrm{L}$ & $\mathrm{F}$ & $\mathrm{LF}$ \\
\hline Undecorticated cotton seed cake & 40 & 25 & 29 & 27 \\
Corn & 22 & 27 & 24 & 25 \\
Wheat & 35 & 41 & 36 & 39 \\
Lupin & - & 4 & - & 2 \\
Fenugreek & - & - & 8 & 4 \\
Limestone & 2 & 2 & 2 & 2 \\
Sodium chloride & 1 & 1 & 1 & 1 \\
\hline
\end{tabular}

$\mathrm{C}=$ control diet, $\mathrm{L}=4 \%$ lupin seeds of $\mathrm{C}$ diet, $\mathrm{F}=8 \%$ fenugreek seeds of $\mathrm{C}$ diet and $\mathrm{LF}=2 \%$ lupin with $4 \%$ fenugreek seeds of $\mathrm{C}$ diet.

Table 2. Chemical (\%) of rations on DM basis

\begin{tabular}{lllll}
\hline Item & \multicolumn{4}{c}{ Rations } \\
\cline { 2 - 5 } & $\mathrm{C}$ & $\mathrm{L}$ & $\mathrm{F}$ & $\mathrm{LF}$ \\
\hline $\mathrm{DM}$ & 92.6 & 91.95 & 92.18 & 92.1 \\
$\mathrm{CP}$ & 18.6 & 18.1 & 18.15 & 18.00 \\
$\mathrm{CF}$ & 12.7 & 13.92 & 11.3 & 9.7 \\
EE & 3.11 & 3.10 & 2.7 & 2.9 \\
NFE & 58.89 & 59.28 & 62.65 & 63.25 \\
OM & 93.4 & 94.4 & 94.8 & 93.85 \\
Ash & 6.6 & 5.6 & 5.2 & 6.15 \\
\hline
\end{tabular}

DM: Dry Matter, OM: Organic Matter, CP: Crude Protein, CF: Crude Fiber ,EE: Ether extract and NFE: Nitrogen free extract. $\mathrm{C}=$ control diet, $\mathrm{L}=4 \%$ lupin seeds of $\mathrm{C}$ diet, $\mathrm{F}=8 \%$ fenugreek seeds of $\mathrm{C}$ diet and $\mathrm{LF}=2 \%$ lupin with $4 \%$ fenugreek seeds of $\mathrm{C}$ diet

\section{Thermo respiratory response parameters:}

Maximum and minimum air temperatures and relative humidity throughout the experimental period were $35,12^{\circ} \mathrm{C}$ and $80,51 \%$, respectively. The THI were 84.63 and $49.20 \%$, respectively according to the following equation after Han et al., 2003, $\mathrm{THI}=((\mathrm{TDB} * 1.8)+32)-((0.55 *(\mathrm{RH} / 100))) * \quad\left(\left(\mathrm{TDB}^{*}\right.\right.$ 1.8)+32)-58). Where: TDB Respiration rate (RR), rectal temperature (RT), skin temperature (ST), ear temperature (ET) and wool surface temperature (WST) measurement were recorded once weekly.

Respiration rate (RR) was expressed as the number of respiration per minute (r.p.m) and was measured by counting the flank movements. Rectal temperature (RT) was measured using clinical thermometer .Skin temperature (ST), ear temperature (ET) and wool Surface temperature (WST) were measured using tele-thermometer.

\section{Blood sampling and analysis:}

Blood samples were obtained from all animals at 9:00 am every month. Blood samples ( $8 \mathrm{ml}$ sample) where collected by jugular vein puncture of each lamb at $2 \mathrm{hrs}$ after the morning feeding and divided into two vials, one dry clean glass vials containing heparin while the other dry clean $10 \mathrm{ml}$ centrifuge tube. Blood samples were allowed to clot at room temperature, serum was then separated by centrifugation at 3000 r.p.m for 15 minutes, then serum was decanted into clean dry glass vials and stored at $20^{\circ} \mathrm{C}$ until subsequent analyses. Various chemical analyses were determined using commercial kits optical density by spectrophotometer (SP6-55 UV/vis, made in England). Packed cell volume (PCV, \%) in blood samples was measured according to a standard method of hematology (Schalm, 1986). The concentration of hemoglobin $(\mathrm{Hb})$ and urea nitrogen, aspartate aminotranferase (AST), alanine aminotransferase (ALT), creatinine and serum glucose were determined using kits supplied by Diamond Diagnostics (Egypt). Serum cholesterol, total protein concentrations, Albumin and Triglyceride were determined by using kits of Biocon (Germany). Serum globulin concentration was calculated as a difference between serum total protein and serum albumin. Albumin/globulin ratio (A/G) was also calculated.

Statistical analysis: The data were statistically analyzed using GLM procedures of SAS (1996) according to the following Statistical model. Yi j k = $\mu+\mathrm{T} \mathrm{i}+\mathrm{M} \mathrm{j}+\mathrm{T} \mathrm{Mi} \mathrm{j}+\mathrm{E} \mathrm{i} \mathrm{j} \mathrm{K,} \mathrm{Where,} \mathrm{Yi} \mathrm{j} \mathrm{K} \mathrm{=}$ experimental observation. $\mu=$ general mean, $\mathrm{Ti}=$ the effect of treatment, $\mathrm{i}=\mathrm{C}, \mathrm{L}, \mathrm{F}$ and LF.M $\mathrm{j}=$ the effect of months, $\mathrm{j}=1,2,3,4,5$ months. $\mathrm{M} \mathrm{i} \mathrm{j}=$ the interaction effect of treatment and months. E I j k = the errors related to individual observation. The significance differences among treatment means were 
tested by Duncan Multiple Range Test (Steel and Torrie, 1980).

\section{RESULTS AND DISCUSSION}

Effect of feeding termis and fenugreek seeds on respiration rates and rectal, skin, ear and wool surface temperatures of Rahmani lambs:

The overall means of respiration rate, rectal temperature and skin, ear and wool temperatures were insignificantly affected by feeding lupin and/or

Table 3. Effect of feeding lupin and fenugreek seeds on thermo- respiratory response of Rahmani lambs

\begin{tabular}{ll} 
Item & \\
\cline { 2 - 2 } & Control $\mathrm{C}$ \\
\hline Respiration rates, breath/min. & $22.88 \pm 0.59^{\mathrm{ab}}$ \\
Rectal temperatures, ${ }^{\circ} \mathrm{C}$ & $39.29 \pm 0.04^{\mathrm{a}}$ \\
Skin temperature, ${ }^{\circ} \mathrm{C}$ & $36.75 \pm 0.10^{\mathrm{ab}}$ \\
Wool surface temperature, ${ }^{\circ} \mathrm{C}$ & $29.84 \pm 0.57^{\mathrm{b}}$ \\
Ear temperature, ${ }^{\circ} \mathrm{C}$ & $30.45 \pm 0.52^{\mathrm{b}}$ \\
\hline${ }^{*}$ values are $\mathrm{LSM}$ means \pm standard error of LSM. ${ }^{\mathrm{a},}{ }^{\mathrm{b}}$ mea \\
$(\mathrm{P}<0.05) . \mathrm{C}=\mathrm{control}$ diet, $\mathrm{L}=4 \%$ lupin seeds of $\mathrm{C}$ diet, $\mathrm{F}=8 \%$ \\
seeds of $\mathrm{C}$ diet \\
Effect of feeding termis and fenugreek seeds on \\
some blood constituents of Rahmani lambs.
\end{tabular}

Feeding either termis or fenugreek containing diets had no significant $(\mathrm{P}>0.05)$ effects on hemoglobin and PCV,\% (Table 4). Similarly, Yones (2005) used lupin seed meal in feeding fish (Sparus aurata) and found no significant effect on hematocrite and hemoglobin values. Also, Tomar et al. (1996) found no effect of feeding fenugreek seeds on hemoglobin in buffaloes.

The overall means of serum glucose concentration in blood of lambs fed lupin and/or fenugreek seeds had no significant differences among treatments (Tables 4 and 5). However, feeding lupin tended to decrease serum glucose during most experimental periods. Serum glucose decreased by 17,26 and $7 \%$ at $1^{\text {st }}, 2^{\text {nd }}$ and $3^{\text {rd }}$ experimental periods (Figure 1). Similar results were found, but to less extent with fenugreek feeding. The hypoglycemic effect of lupin is not found in the literature, However, several investigators reported that fenugreek seeds fenugreek seeds. With the exception that respiration rate and skin, ear and wool temperatures, which tended to increase in animals fed lupin and lupin with fenugreek seeds (Table 3). Such differences may be related to feed intake and/or protein intake in the relevant diets (Soliman et al., 2016). Bianca (1968) and Ulberg (1971) found that rectal temperature was increased due to the increase of feed intake.

Table 4. Effect of feeding lupin and fenugreek seeds on some blood constituents of Rahmani lambs

\begin{tabular}{lcccc}
\hline Item & \multicolumn{4}{c}{ Diet * } \\
\cline { 2 - 5 } & Control C & Lupin (L) & Fenugreck (F) & LF \\
\hline Packed cell volume, PCV\% & $35.4 \pm 1.65^{\mathrm{a}}$ & $34 \pm 2.5^{\mathrm{a}}$ & $34.87 \pm 1.88^{\mathrm{a}}$ & $32.87 \pm 2.70^{\mathrm{a}}$ \\
Hemoglobin, g/dl & $16.74 \pm 0.80^{\mathrm{a}}$ & $15.07 \pm 1.06^{\mathrm{a}}$ & $16.38 \pm 0.79^{\mathrm{a}}$ & $15.96 \pm 0.77^{\mathrm{a}}$ \\
Glucose, mg/dl & $75.88 \pm 2.17^{\mathrm{a}}$ & $66.87 \pm 2.5^{\mathrm{a}}$ & $74.19 \pm 1.33^{\mathrm{a}}$ & $76.79 \pm 1.92^{\mathrm{a}}$ \\
Total protein, g/dl & $6.98 \pm 0.29^{\mathrm{a}}$ & $6.69 \pm 0.28^{\mathrm{a}}$ & $6.47 \pm 0.35^{\mathrm{a}}$ & $7.14 \pm 0.38^{\mathrm{a}}$ \\
Albumin, g/dl & $2.68 \pm 0.12^{\mathrm{a}}$ & $2.74 \pm 0.12^{\mathrm{a}}$ & $2.60 \pm 0.09^{\mathrm{a}}$ & $2.90 \pm 0.14^{\mathrm{a}}$ \\
Globulin, g/dl & $4.31 \pm 0.26^{\mathrm{a}}$ & $3.96 \pm 0.23^{\mathrm{a}}$ & $3.86 \pm 0.35^{\mathrm{a}}$ & $4.23 \pm 0.33^{\mathrm{a}}$ \\
A/G ratio & $0.66 \pm 0.04^{\mathrm{a}}$ & $0.72 \pm 0.04^{\mathrm{a}}$ & $0.75 \pm 0.05^{\mathrm{a}}$ & $0.74 \pm 0.05^{\mathrm{a}}$ \\
Cholesterol, mg/dl & $181.03 \pm 8.4^{\mathrm{ab}}$ & $190.8 \pm 0.60^{\mathrm{a}}$ & $169.7 \pm 3.43^{\mathrm{b}}$ & $177.6 \pm 5.26^{\mathrm{ab}}$ \\
Triglycerides, mg/dl & $151.53 \pm 5.65^{\mathrm{a}}$ & $150.70 \pm 5.73^{\mathrm{a}}$ & $138.98 \pm 3.05^{\mathrm{a}}$ & $153.83 \pm 5.24^{\mathrm{a}}$ \\
Urea nitrogen, mg/dl & $7.73 \pm 0.25^{\mathrm{a}}$ & $8.03 \pm 0.45^{\mathrm{a}}$ & $8.3 \pm 0.59^{\mathrm{a}}$ & $5.81 \pm 0.31^{\mathrm{b}}$ \\
Creatinene, mg/dl & $1.29 \pm 0.10^{\mathrm{a}}$ & $1.4 \pm 0.06^{\mathrm{a}}$ & $1.32 \pm 1.24^{\mathrm{a}}$ & $1.43 \pm 0.70^{\mathrm{a}}$ \\
AST, u/l & $22.00 \pm 2.79^{\mathrm{a}}$ & $24.5 \pm 1.23^{\mathrm{a}}$ & $24.8 \pm 2.06^{\mathrm{a}}$ & $19.13 \pm 2.10^{\mathrm{a}}$ \\
ALT, u/l & $23.8 \pm 2.89^{\mathrm{a}}$ & $23.65 \pm 2.39^{\mathrm{a}}$ & $21.00 \pm 1.62^{\mathrm{a}}$ & $22.33 \pm 2.60^{\mathrm{a}}$ \\
\hline
\end{tabular}

* Values are LSM means \pm standard error of LSM. ${ }^{\text {a, }}{ }^{\mathrm{b}}$ means within the same column or raw having different superscripts $(\mathrm{P}<0.05)$. $\mathrm{C}=$ control diet, $\mathrm{L}=4 \%$ lupin seeds of $\mathrm{C}$ diet, $\mathrm{F}=8 \%$ fenugreek seeds of $\mathrm{C}$ diet, $\mathrm{LF}=2 \%$ lupin with $4 \%$ fenugreek seeds of $\mathrm{C}$ diet. 
Table 5. Effect of feeding lupin and fenugreek seeds on serum glucose concentration (mg/dl) in Rahmani lambs

\begin{tabular}{cccccc}
\hline \multirow{2}{*}{ Month } & \multicolumn{4}{c}{ Treatment } \\
\cline { 2 - 5 } & \multicolumn{1}{c}{ Control (C) } & \multicolumn{2}{c}{ Lupin (L) } & Fenugreck (F) & LF \\
\hline 1 & $83.56 \pm 7.26^{\mathrm{a}}$ & $69.04 \pm 5.47^{\mathrm{a}}$ & $78.41 \pm 4.43^{\mathrm{a}}$ & $81.59 \pm 5.97^{\mathrm{a}}$ \\
2 & $77.77 \pm 6.71^{\mathrm{a}}$ & $57.69 \pm 5.60^{\mathrm{b}}$ & $72.77 \pm 7.32^{\mathrm{a}}$ & $78.23 \pm 7.76^{\mathrm{a}}$ \\
3 & $72.08 \pm 1.34^{\mathrm{a}}$ & $67.02 \pm 2.40^{\mathrm{a}}$ & $70.41 \pm 3.16^{\mathrm{a}}$ & $70.33 \pm 2.97^{\mathrm{a}}$ \\
4 & $73.26 \pm 7.20^{\mathrm{a}}$ & $68.30 \pm 6.64^{\mathrm{a}}$ & $74.17 \pm 4.06^{\mathrm{a}}$ & $78.63 \pm 4.24^{\mathrm{a}}$ \\
5 & $72.77 \pm 7.85^{\mathrm{a}}$ & $72.33 \pm 5.04^{\mathrm{a}}$ & $75.19 \pm 7.95^{\mathrm{a}}$ & $75.17 \pm 9.48^{\mathrm{a}}$ \\
Overall mean & $75.88 \pm 2.17^{\mathrm{a}}$ & $66.87 \pm 2.5^{\mathrm{a}}$ & $74.19 \pm 1.33^{\mathrm{a}}$ & $76.79 \pm 1.92^{\mathrm{a}}$ \\
\hline
\end{tabular}

* Values are LSM means \pm standard error of LSM. ${ }^{\text {a, }}$ b means in the same column or raw with different superscripts are significant different $(\mathrm{P}<0.05)$. $\mathrm{C}=$ control diet, $\mathrm{L}=4 \%$ lupin seeds of $\mathrm{C}$ diet, $\mathrm{F}=8 \%$ fenugreek seeds of $\mathrm{C}$ diet, $\mathrm{LF}=2 \%$ lupin with $4 \%$ fenugreek seeds of $C$ diet.

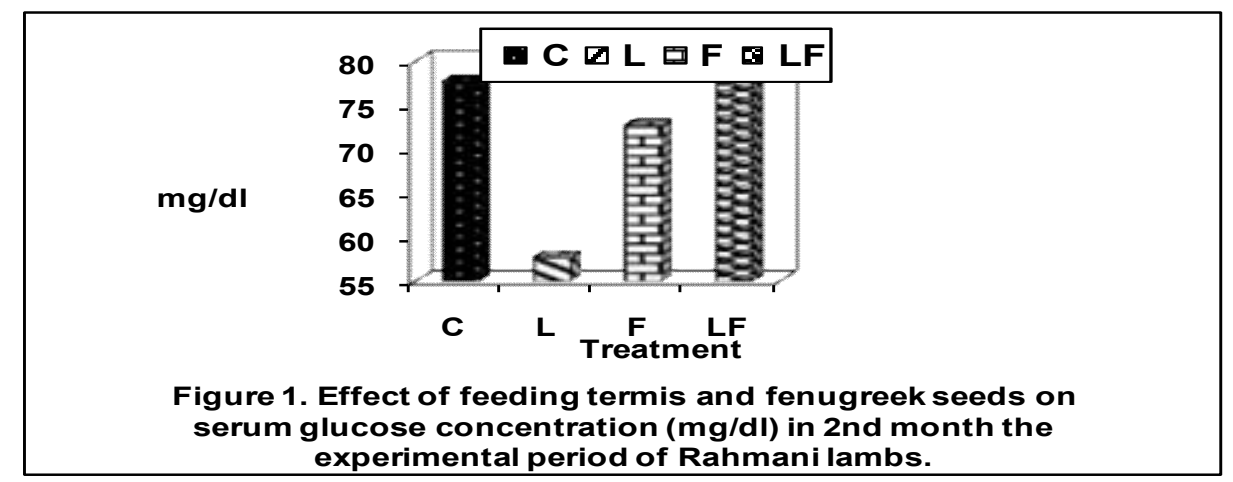

The overall means of serum total protein concentration had no significant $(\mathrm{P}>0.05)$ differences among treatments. However, lambs fed on a diet containing fenugreek seeds tended to have less serum total proteins than other treatments (Table 5). Also, Rashwan (1998) found similar decrease $(\mathrm{P}<0.01)$ in serum total protein in rabbits fed diet containing fenugreek seeds. However, animals fed on termis with fenugreek tended to have higher values of serum total protein, but such differences were not significant (Table 4).

Also, serum albumin and globulin concentrations were not significantly affected by treatments (Tables 4). Dietary lupin and/or fenugreek tended to increase serum albumin at $5^{\text {th }}$ month of the experimental period (Figure 2). Such results were mainly related to the increase of albumin concentration in blood of these animals, which attributed to difference in feed intake (Al-Khateb, 2008). He found that, feed intake increased by about $16,8 \%$ and $30 \%$ due to feeding lupin, fenugreek and lupin with fenugreek diets, respectively, compared to the control diet. Similarly, Harper (1975) indicated that serum albumin is synthesized in the liver from amino acids. The increase in these parameters may be attributed to the increase in protein digestibility coefficient (Fouad, 2001), improved nitrogen absorption (Kornegay et al., 1997), increased amino acids synthesis in liver (Moonsie-Shageer and Mowat, 1993) and /or improved immunity function (Habeeb et al., 2001). Hallford et al. (1982) found that high protein intake increased serum albumin concentration. Values of $\mathrm{A} / \mathrm{G}$ ratio during different experimental periods are shown in table 5. $\mathrm{A} / \mathrm{G}$ ratio tended to increase in blood of animals fed on lupin and/or fenugreek seeds (Figure 3). However such differences were not significant.

The overall means of serum cholesterol concentration of lambs were not significantly affected by dietary lupin and lupin with fenugreek. However, fenugreek feeding tended to decrease serum cholesterol. Serum cholesterol concentration decreased by about 7 and $15 \%$ due to fenugreek feeding at $1^{\text {st }}$ and $3^{\text {rd }}$ periods of the experimental period (Tables $4 \& 6$ ).

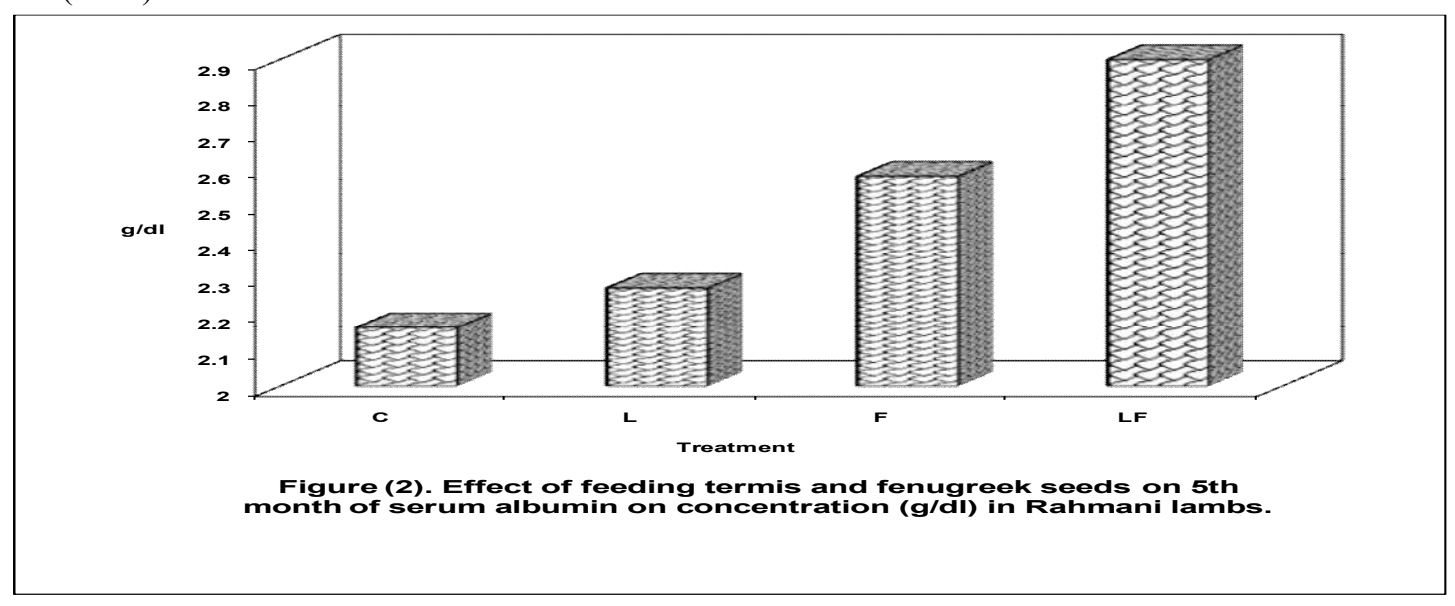




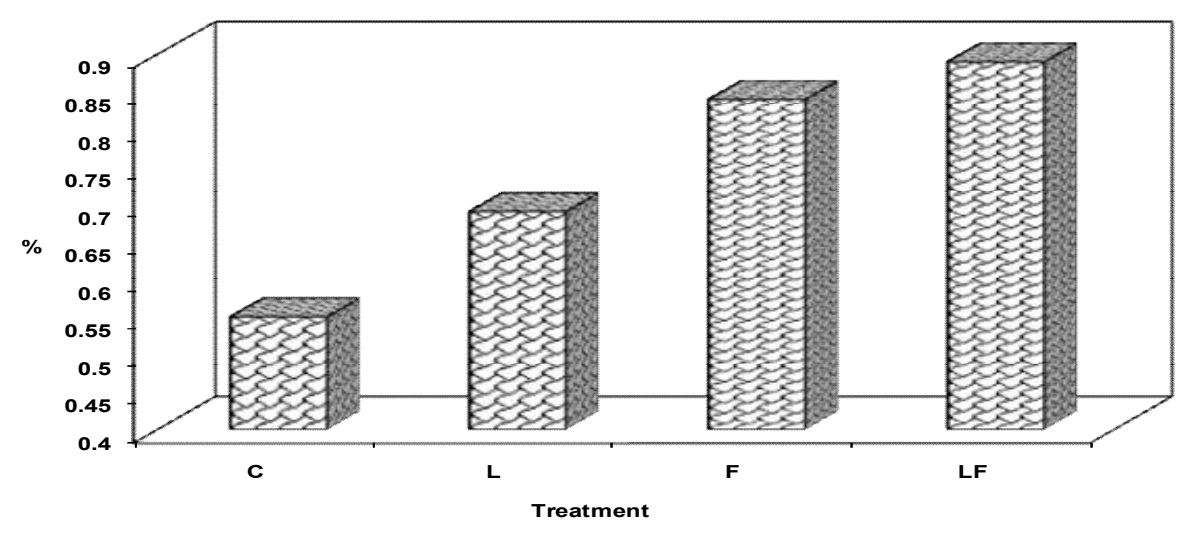

Figure(3). Effect of feeding termis and fenugreek seeds on A/G ratio at 5th month of experimental period in Rahmani lambs.

Table 6. Effect of feeding lupin and fenugreek seeds on serum cholesterol constituents of Rahmani lambs

\begin{tabular}{|c|c|c|c|c|}
\hline \multirow[t]{2}{*}{ Period, month } & \multicolumn{4}{|c|}{ Treatment* } \\
\hline & $\begin{array}{l}\text { Control } \\
\mathbb{C}\end{array}$ & Lupin (L) & $\begin{array}{l}\text { Fenugreck } \\
\text { (F) }\end{array}$ & $\mathbf{L F}$ \\
\hline 1 & $181.63 \pm 9.74^{\mathrm{a}}$ & $191.53 \pm 11.90^{\mathrm{a}}$ & $168.83 \pm 3.54^{b}$ & $167.63 \pm 15.69^{b}$ \\
\hline 2 & $195.00 \pm 2.88^{\mathrm{a}}$ & $189.66 \pm 7.65^{\mathrm{a}}$ & $165.43 \pm 3.12^{\mathrm{b}}$ & $180.03 \pm 7.51^{\mathrm{a}}$ \\
\hline 3 & $166.46 \pm 3.41^{\mathrm{b}}$ & $191.36 \pm 4.66^{\mathrm{a}}$ & $174.90 \pm 5.35^{\mathrm{a}}$ & $185.13 \pm 7.53^{\mathrm{a}}$ \\
\hline Overall mean & $181.03 \pm 8.4^{\mathrm{ab}}$ & $190.8 \pm 0.60^{\mathrm{a}}$ & $169.7 \pm 3.43^{\mathrm{b}}$ & $177.6 \pm 5.26^{\mathrm{ab}}$ \\
\hline
\end{tabular}

* Values are LSM means \pm standard error of LSM. ${ }^{\text {a, }}{ }^{b}$ means in the same column or raw with different superscripts are significant different $(\mathrm{P}<0.05)$. $\mathrm{C}=$ control diet, $\mathrm{L}=4 \%$ lupin seeds of $\mathrm{C}$ diet, $\mathrm{F}=8 \%$ fenugreek seeds of $\mathrm{C}$ diet, $\mathrm{LF}=2 \%$ lupin with $4 \%$ fenugreek seeds of $C$ diet.

Similarly, Sharma et al. (1990) found hypocholesterolemic effect of dietary fenugreek. Such effect may be related to the galactomannan effect in seeds (Madar and Shomer, 1990), and/or stimulation effect of fenugreek on adrenal steroids (Suresh- Babu and Srinivasan, 1993). Due to its diosgenin, a steroidal saponin belonging to the group of triterpense, is of great interest in the pharmaceutical industry since it has an estrogenic effect on the mammary gland, plays an important role in the control of cholesterol metabolism (Ortuno et al., 1999). Stark and Madar (1993) showed that reduction in plasma cholesterol levels ranged from 18 to $26 \%$ and a tendency for lower concentrations of liver cholesterol was observed. It appears that saponins interact with bile salts in the digestive tract. Serum cholesterol showed significant $(\mathrm{P}<0.01)$ reduction with dietary fenugreek addition to rabbits diets (Rashwan, 1998). $\mathrm{He}$ found that the administration of saponins also induces a significant reduction of serum cholesterol $(\mathrm{P}<0.01)$ and reported that these aglycones effect cholesterol metabolism in liver, saponins inhibit cholesterol absorption from intestine (Newman et al., 1957). Saponins are present in fenugreek seeds in the form of glycosides, such as diosgenin and gigtogenin (CSIR, 1976). Negulesco et al. (1985) determined the effect on plasma total cholesterol and triglycerides, when capsaicin is administered at the dose of $8 \mathrm{mg} / \mathrm{animal} /$ day to young female rabbits maintained on a $0.5 \%$ cholesterol diet over a five week experimental period. The data indicated that mammals fed cholesterol rich diets and supplemented with capsaicin show decreased plasma total cholesterol and triglyceride. The mechanism of this effect is probably due to decreased intestinal absorption of the lipids. Sharma (1986) reported that fenugreek seeds were found to be effective in lowering elevated serum cholesterol levels as well as in preventing an elevation when fed together with a hypercholesterolemia inducing diet. The effects of fenugreek seeds were due to both the fiber and the saponins. Also, fenugreek seed have hypoglycemic effect (Table 5) and since hypercholesterolemia is secondary to diabetes, fenugreek seed or its defatted seed fraction may be useful in the treatment of diabetes. Interestingly, defatted seeds are not bitter in taste and contain a good amount of protein $(25 \%)$. They can be exploited commercially as therapeutically useful foods for hypercholesterolemic and diabetic patients. The overall means of triglyceride levels ranged between 138.98 and 153.83 $\mathrm{mg} / \mathrm{dl}$ in animals fed fenugreek. However, serum triglycerides concentration tended to decrease in animals fed termis or fenugreek at $1^{\text {st }}, 2^{\text {nd }}$ and $4^{\text {th }}$ months of experimental periods. Serum triglycerides decreased by about 16 and $15 \%$ due to lupin and fenugreek feeding at $2^{\text {nd }}$ month of the experimental period, the corresponding values at $4^{\text {th }}$ month of the experimental period were 10 and $11 \%$, respectively (Table 7). 
Table 7. Effect of feeding lupin and fenugreek seeds on serum triglycerides constituents in Rahmani lambs

\begin{tabular}{rcrrc}
\hline Period, month & \multicolumn{4}{c}{ Treatment* } \\
\cline { 2 - 5 } & Control $C$ & lupin(L) & fenugreek(F) & LF \\
\hline 1 & $165.10 \pm 11.17^{\mathrm{a}}$ & $137.60 \pm 6.52^{\mathrm{a}}$ & $140.73 \pm 25.26^{\mathrm{a}}$ & $173.10 \pm 16.91^{\mathrm{a}}$ \\
2 & $145.03 \pm 22.56^{\mathrm{a}}$ & $143.13 \pm 9.02^{\mathrm{a}}$ & $129.00 \pm 6.72^{\mathrm{a}}$ & $156.07 \pm 5.80^{\mathrm{a}}$ \\
3 & $144.83 \pm 10.60^{\mathrm{a}}$ & $154.17 \pm 17.79^{\mathrm{a}}$ & $143.83 \pm 15.10^{\mathrm{a}}$ & $147.10 \pm 18.13^{\mathrm{a}}$ \\
4 & $164.83 \pm 11.94^{\mathrm{a}}$ & $147.83 \pm 18.95^{\mathrm{a}}$ & $145.87 \pm 16.45^{\mathrm{a}}$ & $149.90 \pm 17.37^{\mathrm{a}}$ \\
5 & $137.90 \pm 19.76^{\mathrm{a}}$ & $170.80 \pm 20.86^{\mathrm{a}}$ & $135.50 \pm 14.56^{\mathrm{a}}$ & $143.00 \pm 31.74^{\mathrm{a}}$ \\
Overall mean & $151.53 \pm 5.65^{\mathrm{a}}$ & $150.70 \pm 5.73^{\mathrm{a}}$ & $138.98 \pm 3.05^{\mathrm{a}}$ & $153.83 \pm 5.24^{\mathrm{a}}$ \\
\hline
\end{tabular}

* Values are LSM means \pm standard error of LSM. ${ }^{\mathrm{a},}{ }^{\mathrm{b}}$ means in the same column or raw with different superscripts are significant different $(\mathrm{P}<0.05)$. $\mathrm{C}=$ control diet, $\mathrm{L}=4 \%$ lupin seeds of $\mathrm{C}$ diet, $\mathrm{F}=8 \%$ fenugreek seeds of $\mathrm{C}$ diet, $\mathrm{LF}=2 \%$ lupin with $4 \%$ fenugreek seeds of $C$ diet.

Serum urea-nitrogen concentrations were significantly $(\mathrm{P}<0.05)$ lower in lambs fed lupin with fenugreek seeds than those fed the control diet. However, feeding lupin or fenugreek tended to increase serum urea- nitrogen of lambs. But such differences were not significant. This result indicates that, feeding either lupin or fenugreek seeds had no effect on kidney function (Table 4). Kaneko (1981) found that the normal range of urea nitrogen concentration were 17 to $43 \mathrm{mg} / \mathrm{dl}$. The overall means of serum creatinine concentrations tended to be higher in animals fed lupin and/or fenugreek seeds. However, such differences among treatments were not significant (Table 4). Blood creatinine is a product of nitrogen metabolism, the rate of blood creatinine production may be considered as an index of endogenous protein catabolism (Patrick et al., 1998) or kidney functions. The present result means no deleterious effect of feeding either lupin or fenugreek on kidney function. Similar result was found by Rashwan (1998). He reported that serum creatinine $(1.10 \mathrm{mg} / \mathrm{dl})$ was not significantly affected by feeding $12 \mathrm{~g}$ fenugreek seeds/kg diet in New Zealand white doe rabbit.

The overall means of serum AST and ALT concentrations were not significantly affected by feeding either lupin or fenugreek seeds (Table 4). In other words, the values of AST and ALT in the present study falls within the normal physiological values and feeding either lupin or termis had no deleterious effect on liver function. However, Nakhla et al. (1991) reported that AST activity was elevated by fenugreek crude seed saponins diets for broiler chicks. However, this result may be related to constituents such as trigonelline and saponins alkaloids which cause the bitter taste of fenugreek. Mohamed (1996) found that fenugreek could be developed to be the most attractive plant cultivated as a source of diosgenin and trigonelline alkaloids. Therefore, fenugreek seeds contain sapogenins used for medicinal steroid synthesis and isognino lizidene alkaloid. Accordingly, Muralidhara et al. (1999) indicated that debitterized fenugreek powder does not produce any significant effect on the levels of AST and ALT.

\section{CONCLUSION}

Lupin or fenugreek seeds tended to have hypoglycemic effects, Fenugreek seeds tended to decrease serum cholesterol and Feeding both lupin and fenugreek seeds had no deleterious effects on kidney or liver function.

\section{REFERENCES}

Abol-Fotouh, G. E., S. M. Allam, E. Shehata and N. Abd El-Azeem, 1999. Effect of some medicinal plants as feed additives on performance of growing sheep. Egypt. J. Nutr. Feeds. 2: 79.

Al-Khateb, A. S., 2008. Growth Performance, Some Physiological Parameters and Nutrients Digestibility in Rahmani Lambs Fed on Diets Supplemented with Termis and Fenugreek. M Sc Thesis, Assiut University.

Ajabnoor, M. A., and A. K. Tilmisany, 1988. Effect of Trigonella foenum graecum on blood glucose levels in normal and alloxan diabetic mice. J. Ethnopharmcology, 22: 45.

Allam, M. S., H. M. El-Husseiny, A. M. Abdel Gawad, S. A. El-Saadany and A. M. M. Zeid, 1999. Medicinal herbs and plants as feed additives for ruminants. 1- Effect of using some medicinal herbs and plant as feed additives on Zaraibi goat performance. Egypt. J. Nutr. Feeds. 2: 349 .

Bianca, W., 1968. Thermoregulation. In: E. S. Hafez (Ed.), Adaptation of Domestic Animals, pp. 99109, Lea and Febiger, Philadelphia.

CSIR, 1976. The Wealth of India Raw Material Vol X P-W. Publication and Information Directroate CSIR, New Delhi. 302.

El-Ayek, M. Y., A. A. Gaber and A. Z. Mehrez, 1999. Influence of substituting concentrate feed mixture by Nigella Sativa meal on animal performance and carcass traits of growing lambs. Egypt. J. Nutr. Feeds, 2 ( special issue ): 265.

El-Saadany, S. A., M. M. Mohey El-Din, I. A. Abou Ismail, S. M. Mohamed and N. M. El-Kholy, 1999. Effect of Some Medicinal herbs as feed additives on buffalo Milk. Egypt. J. Nutr. Feeds. 2 (special issue): 505 .

Fouad, R. T. 2001. Effect of replacing concentrate feed mixture by barley grains on Se, edi lambs performance in upper Egypt .J. Agric. Sci. Mansoura Univ. 26 (12): 7619.

Gaber, A. A., S. A. El-Ayouty, A. A. Zaki, F. E. Abou Ammo and E. S. I. El-Gohary, 1996. Productive performance of lambs fed diets 
containing Nigella sativa meal. Egypt. J. Nutr. Feeds. 1(2): 97.

Habeeb, A. A. M, A. E. B. Zeidan and A. A. Shitta, 2001. The role of niacin and Sprinkling in improving milk yield. Composition and biochemical functions of the heat stressed Friesian cows. Egypt. J. Nutr. Feeds. 4: 285.

Hallford, M. E., D. G. Morrical, M. Schoene, H. E. Kiesling and G. S. Smith, 1982. Influence of short-term consumption of sewage solids on productivity of fall-lambing ewes and performance of their offspring. J. Anim. Sci. 54: 922.

Hanafy, M. M. 1995. The use of anise, fennel and ginger as a feed additive in the nutrition of broilers. M. Sc. thesis, Fac. Agric., Alexandria Univ., Egypt.

Harper, H.A., 1975. The blood lymph and cerebrospinal fluid. In: "Review of Physiological Chemistry". pp: 194-219 (15 ${ }^{\text {th }}$ Ed.). Los Altos, California. USA.

Kaneko, F., 1981. Clinical biochemistry of domestic animal. Third Ed. Academic Press, New York, NY

Karaly, M.A., 1995. The use of coriander, peppermint and celery as feed additives in Pekin Ducks, M. Sc. Thesis, Fac. Agric., Alexandria Univ., Egypt.

Khosla, P., D. D. Gupta and R. K. Nagpal, 1995. Effect of Trigonella foenum graecum (fenugreek) on Blood glucose in normal and diabetic rats. indian. J. physiol. pharmacol. 39 (2): 173.

Kobeisy, M. A., I. A. Salem and M. Zenhom, 1997. The effect of giving ascorbid acid on some physiological and hematological parameters of suckling lambs exposed to solar radiation and exercise. Assiut Vet. Med. J. 37: 120.

Kornegay, E. T., Z. Wang, C. M. Wood and M. D. Lindemann. 1997. Supplemental chromium piolinte influences nitrogen balance, dry matter digestibility and carcass traits in growingfinishing pigs. J. Anim. Sci. 75: 1319.

Madar, Z., and L. Shomer, 1990. Polysaccharide composition of a get fraction derived from fenugreek and its effect on starch digestion and bile acid absorption in rats. J. Agric. Food Chem. 38: 1535.

Matsuo, T., M. Yoshioka and M. Suzuki, 1996. Capsaicin in diet does not affect glycogen contents in the liver and skeletal muscle rate before and after exercise. J. Nutr. Sci. and Vitaminology. 42: 249.

Mir, Z., P. S. Mir, S. N. Acharya, M. S. Zaman, W. G. Taylor, G. J. Mears, T. A. McAllister and L. A. Goonewardene, 1998. Comparison of alfalfa and fenugreek (Trigonella foenum-graecum) Silages supplemented with barley grain on performance of growing steers. Can. J. Anim. Sci. 78: 343 .
Mohamed, M. S., 1996. Biochemical studies of fenugreek by using tissue culture techniques. M. Sc. Thesis, Fac. of Agric., Cairo Univ., Egypt.

Moonsie-Shageer, S. and D. N. Mowat, 1993. Effect of level of supplemental chromium on performance, serum constituents and immune status of stressed feeded calves .J. Anim. Sci. 71: 232.

Muralidhara, N. K., S. Viswanatha and B. S. Ramesh, 1999. Acute and sub chronic toxicity assessment of debitterized fenugreek powder in the mouse and rat. Food Chem. Toxicol. 37: 831.

Nakhla, H. B., O. S. Mohamed, I. M. Abu, A. L. Fatuh and S. E. Adam, 1991. The effect of Trigonella foenum graecum (fenugreek) crude saponins on Hisex type chicks. Vet. Hum. Toxicol. 33(6): 561.

Negulesco, J. A., R. M. Young and P. Ki, 1985. Capsaicin lowers plasma cholesterol and triglycerides lagomorphs. Artery. 12: 301.

Newman, M. A., F. A. Kummerov and H. H. Scott, 1957. Dietary Saponin, a factor which may reduce liver and serum cholesterol levels. Poult. Sci. 37: 42.

Ortuno, A., R. Oncina, J. M. Botia and J. A. DelRio, 1999. Regulation of the diosgenin expression in Trigonella foenum graecum plants by different plant growth regulators. Food Chem. 65: 227.

Patrick, G. H., J. A. Hopkins, W. S. Ramsey and A. Gilmore, 1998. Effect of level of protein and type of molasses on digesta kinetics and blood metabolites in sheep. Small Rumin. Res. 28: 161.

Rashwan, A. A., 1998. Effects of dietary additions of anise, fenugreek and caraway on reproductive and productive performance of New Zealand white rabbit does. Egypt. J. of Rabbit Sci. 8: 157.

Saito, A., K. Nakamura, Y. Hori and M. Yamamoto, 1999. Effects of Capsaicin on Serum triglycerides and free fatty acids in olive oil treated rats. International J. For Vitamin and Nutr. Res. 69: 337.

SAS, 1996. Statistical Analysis System. User's Guide. Inst., Inc., Cary, NC.

Shalaby, S. M.M., 2004. Response of Nile tilapia, Oreochromis niloticus, fingerlings to diets supplemented with different levels of fenugreek seeds (Hulba). J. Agric. Sci. Mansoura Univ., 29 (5): 2231 .

Sharma, R. D., 1986. An evaluation of hypocholesterolemic factor of fenugreek seeds (T. Foenum graecum) in rats. Nutr. Rep. Int. 33: 669.

Sharma, R. D., T. C. Raghuram and N. S. Rao, 1990. Effect of fenugreek seeds on blood glucose and serum lipids in type I diabetes. Eur. J. Clin . 40 (4): 301.

Stark, A. and Z. Madar, 1993. The effect of an ethanol extract derived from fenugreek (Trigonella foenum-graecum)on bile acid absorption and cholesterol levels in rats. Br. J. Nutr. 69 (1): 277 
Steel, R. G. and J. H. Torrie, 1980. "Principles and Procedures of Statistics". A Biometrical Approach (2 ${ }^{\text {nd }}$ Ed.) McGrow-Hill Book, New York.

Suresh-Babu, P. and K. Srinivasan. 1993. Influence of dietary spices on adrenal steroidogensis in rats. Nutr. Res. 13: 435.

Teleni, E., J. B. Rowe, K. P. Croker, P. J. Murray and W. R. King, 1989. Lupins and energyyielding nutrients in ewes. 2-responses in ovulation rate of ewes to increased availability of glucose, acetate and amino acids. Reprod. Fert. Dev. 1:117.

Tomar, K. S., V. P. Singh and R. S. Yadav, 1996. Effect of feeding maithy (Trigonella foenumgraecum) and Chandrasoor (Lepidium sativum L.) seeds on milk and blood constituents of Murrah buffaloes. Indian J. Anim. Sci. 66 (11): 1192.
Ulberg, L. C., 1971. Animal characteristics in relation to environmental response In: Aguide to Environmental research on Animals, Committee on Agricultural board, pp. 189-198, National Research Council, National Academy of Science, Washington, D. C.

Yones, A. M., 2005. Incorporation of lupin seed meal as plant protein source in gilthead sea bream (Sparus aurata) diets. J. Agric. Sci. Mansoura Univ., 30 (11): 6553.

Youssef, M. M., A. M. Abdinene, R. M. Khattab and S. A. Darwish, 1998. Effect of feeding Nigella sativa cake on productive and reproductive performance of buffaloes. Egypt. J. Nutr. Feeds. 1: 73 .

\section{تأثير التغذية بحبوب الترمس والحلبة على الإستجابة الحراريةـ تتفسيه وبعض مكونات الام فى أغنام الرحمانى مصطفى قبيصى، ابراهيم سليمان، سالم محمد، أسعد الخطي ا قسم الإنتاج الحيوانس، كلية الزراعة، جامعة أسبيوط، أسبيوط ب قسم الإنتاج الحيوانس، كلية الزراعة جامعة الأزهر، أسبيوط}

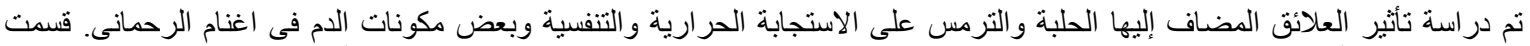

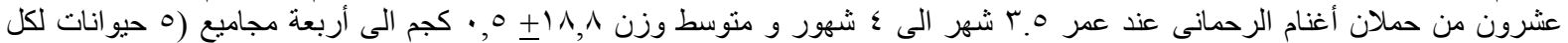

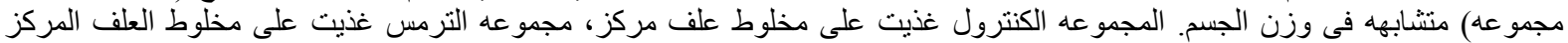

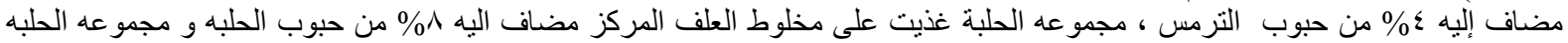

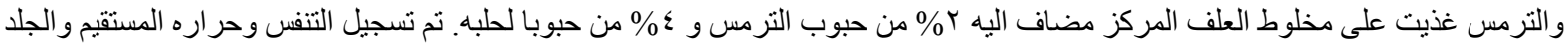

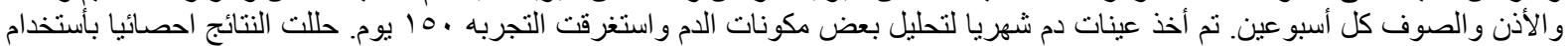

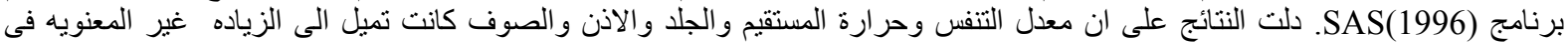

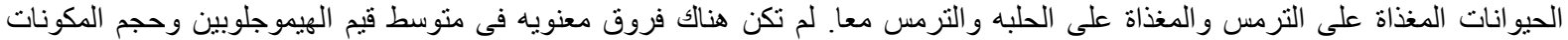

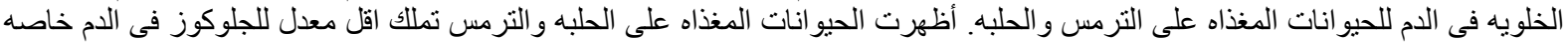

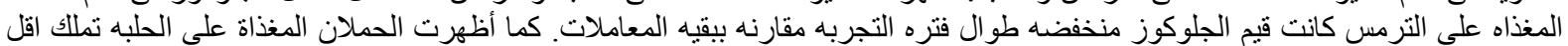

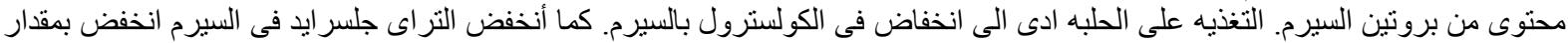

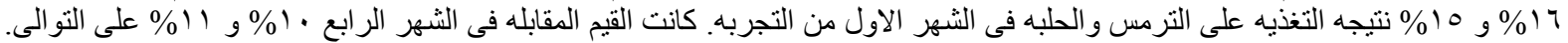

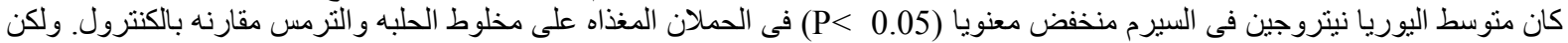

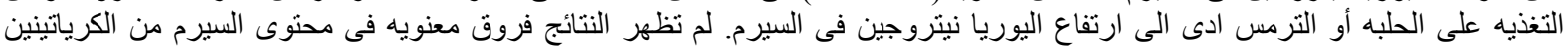

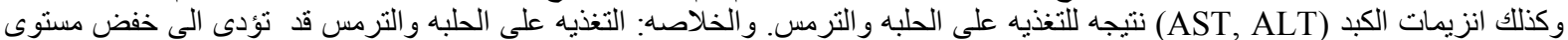
السكر فى الدم . الحلبه قد يكون لها تأثثر مخفض للكوليسترول فى الدم. التغذيه بالحلبه أو الترمس ليس لهما تأثير ضار على وظائف الكبد و الكلى. 